\title{
Residues of Citrus sinensis (L.) Osbeck as agents that cause a change in antioxidant defense in plants
}

\author{
Patrícia Mayra Pavan Nunes ${ }^{1, *}$, Cristiane Bezerra da Silva1, Cristiane da Silva Paula1, Fernanda \\ Ferreira Smolarek ${ }^{1}$, Walmes Marques Zeviani ${ }^{3}$, Suelen Cristina Chaves ${ }^{1}$, Fernando Lorini ${ }^{2}$, Josiane \\ de Fátima Gaspari Dias ${ }^{1}$, Obdulio Gomes Miguel ${ }^{1}$, Sandra Maria Warumby Zanin¹, Marilis \\ Dallarmi Miguel ${ }^{1}$
}

\author{
${ }^{1}$ Departament of Pharmacy, Federal University of Paraná, Curitiba, PR, Brasil, ${ }^{2}$ Departamento of Chemistry, Federal \\ University of Paraná, Curitiba, PR, Brasil, ${ }^{3}$ Departamento of Statistics, Federal University of Paraná, Curitiba, PR, Brasil
}

\begin{abstract}
This work aimed to verify the allelopathic potential of the extract of Citrus seeds, for the purpose of adding a sustainable value to the fruit seeds toward their use as industrial residues. The extract was obtained with a Soxhlet apparatus by using hexane, chloroform, and methanol as solvents. The hexane extract of the Citrus seeds primarily consisted of linoleic acid (36.6\%), followed by $\alpha$-linoleic acid (25.3\%), oleic acid (17.8\%), palmitic acid (9.7\%), and estearic acid (3.3\%). The analysis results indicate that the oil is similar to those used in the cosmetics and food industries and has an economic value from its industrial application. In addition, the use of the oil causes changes in the oxidant balance, germination, and growth of plants.
\end{abstract}

Uniterms: Citrus sinensis (L.) Osbeck/residues/utilization. Citrus sinensis (L.) Osbeck/seeds/allelopathic potential. Rutaceae/residues/utilization. Fixed oil. Fatty acid.

\begin{abstract}
Este trabalho teve como objetivo verificar o potencial alelopático do extrato de sementes de Citrus, com o objetivo de agregar valor sustentável para a semente de frutas para a sua utilização como resíduo industrial. O extrato foi obtido com aparelho de Soxhlet, utilizando hexano, clorofórmio e metanol como solventes. O extrato hexânico das sementes de Citrus constituiu principalmente por ácido linoleico (36,6\%), seguido por ácido $\alpha$-linoleico $(25,3 \%)$, ácido oleico $(17,8 \%)$, ácido palmítico $(9,7 \%)$ e ácido esteárico (3,3\%). As análises indicam que o óleo é semelhante aos utilizados na indústria de cosméticos e de alimentos, tem valor econômico para a utilização na indústria e seu uso provoca alterações no equilíbrio oxidativo, germinação e crescimento.
\end{abstract}

Unitermos: Citrus sinensis (L.) Osbeck/resíduos/utilização. Citrus sinensis (L.) Osbeck/sementes/ potencial alelopático. Rutaceae/resíduos/utilização. Óleo fixo. Ácido graxo.

\section{INTRODUCTION}

Allelopathy is a regular practice for controlling weeds and could represent a good approach to reduce the use of pesticides. However, the use of allelochemicals may influence the development of other organisms by causing various effects, such as a reduction in nutrient absorption, inhibition of photosynthesis, changes in the

\footnotetext{
*Correspondence: P.M.P. Nunes. Departamento de Farmácia. Universidade Federal do Paraná-Campus III. Av. Pref. Lothário Meissner, 632 - Jardim Botânico - 80210-170 - Curitiba, PR, Brasil. E-mail: patympn@yahoo.com.br
}

respiratory system that could accelerate or diminish the plant respiration, as well as changes in growth hormones, dismutase antioxidant defense, protein synthesis, and membrane permeability and enzyme activity inhibition (Mauli et al., 2009; Pergo,Ishii-Iwamoto, 2011).

The toxicity of reactive oxygen species (ROS), which causes oxidative damage to cell macromolecules, is well documented (De Wit, 2007; Chen, 2008). There is evidence that ROS also play normal physiologic roles, acting as signaling molecules in many processes, including seed germination and growth (Ryan, 2000; Chen, 2008). The shift from a normal role in cell signaling to a toxic 
role with deleterious effects is probably associated with changes in ROS homeostasis that result from a shift in the balance between ROS-producing and ROS-scavenging processes (Pergo, Ishii- Iwamoto, 2011).

Cell growth in plants depends on a normal mitotic process. The growth-limiting effects of various kinds of stress have been reported as factors in the control of cell division (Ding et al., 2010). The uniform division of all cell components allows balanced growth for the organism (Reigosa et al., 2006). Mitotic activity, alterations in the mitotic phase, and individual cell abnormalities are key parameters by which plant growth may be evaluated (Teerarak, Laosinwattana, Charoenying, 2010). Onion or lettuce tests are standard techniques for cytogenetic assays in environmental monitoring because the data obtained from these plants show a correlation between mammalian and nonmammalian test systems (Schmidt-Silva et al., 2011).

The genus Citrus belongs to the Rutaceae family and has a vast distribution, mainly in tropical and subtropical regions (Manner et al., 2006). Brazil is one of the biggest Citrus-producing countries, with a mean yield of 20-25 tons/hectare (Mahmood, 2005; Khan, 2005; Di Bella et al., 2010). The production growth in food industries has caused an increase in the production of Citrus residues (seeds). These residues, originated from in nature consumption, are more often totally discarded, causing problems of environmental contamination because the waste is more likely to be degraded by microorganisms. Thus, the use of these residues in an efficient, economic, and environmentally safe manner is especially important in view of their potential profitability and applications (Schieber, Stintzing, Carle, 2001).

This work aimed to investigate the application of residues of $C$. sinesis seeds given their biological potential. Thus far, there has been no study regarding their potential application as natural herbicides, having substances that may be used in the control of weeds, or as an environmentally safe option for eliminating industrial residues. The parameters of respiratory activity, total chlorophyll, and antioxidant enzyme activity implicated in ROS balance were measured during the germination and growth of lettuce (Lactuca sativa L. cv. Grand Rapids). The enzyme activities measured in these plants included superoxide dismutase (SOD), catalase (CAT), peroxidase (POD), ascorbate peroxidase (APX), and polyphenol oxidase (PPO).

\section{MATERIAL AND METHODS}

Citrus fruits were collected at Jardim Alegre in Paraná, Brazil, and the species sample was kept in the
Botanical Garden of Curitiba (MBM), also in Paraná, with the label number 11784 . The fruits were fractionated. Then the seeds were selected by hand, washed with water, and dried at $40{ }^{\circ} \mathrm{C}$ in a greenhouse with air circulation for $19 \mathrm{~h}$. The seeds were placed in a glass flask, which was then closed and labeled. They were stored in a room without light and humidity and kept at room temperature until use. To obtain the extracts, the seeds were subjected to extraction of hexane, and then of chloroform and methanol, through percolation with a Soxhlet apparatus for $6 \mathrm{~h}$; the extracts were then concentrated in a rota-steam at $60{ }^{\circ} \mathrm{C}$. Hexane (FH), chloroform (FCL), and methanol (FM) fractions were obtained.

\section{Determination of fatty acids on hexane fraction}

The fatty acids were identified by gas chromatography, and the corresponding peaks of saturated and unsaturated fatty acids were detected. For the analysis, an Agilent 6850 gas chromatograph, the EZChrom SI software, a flame ionization detector, and a column of DB-23 stainless steel (60 m x 0.25 internal diameter $\times 0.25$ film) with a stationary phase (50\% cyanopropyl) methylpolysiloxane were used. For the derivatization, $100 \mathrm{mg}$ of oil was added to a mixture of $10 \mathrm{~mL}$ of hexane and $100 \mu \mathrm{L}$ of $0.2 \mathrm{~N} \mathrm{KOH}$, which was then shaken in a vortex for 5 minutes. Glycerin was decanted, and the supernatant was added directly into the vial; $1 \mu \mathrm{L}$ of the sample was injected and with a chromatography under current conditions of $30 \mathrm{~mL} / \mathrm{min}$ of hydrogen gas, an injector temperature of $250^{\circ} \mathrm{C}$, and a detector temperature of $280^{\circ} \mathrm{C}$. The determination of oil components was done through comparison of the Kovats retention indexes with those described by Adams (1995).

\section{Germination and growth bioassays}

The allelopathic effects of the fractions were evaluated during the germination and growth of lettuce (Lactuca sativa L. cv. Grand Rapids) bought in a local commerce. To prepare the solutions, the fractions (FH, FCL, and FM) were first weighed with an analytical balance, taking into account the water content. The stock solutions (1000 mg.mL $\mathrm{m}^{-1}$ ) were prepared from the mass calculated for each fraction and dissolved in dimethylsulfoxide (DMSO) at 0.1\% (Dayan, Romagni, Duke, 2000); 500 and $250 \mathrm{mg} \cdot \mathrm{mL}^{-1}$ concentrations were then prepared by dilution. The solutions were packed with a solution of $10 \mathrm{mM}$ 2-morpholinoethanesulfonic acid (MES); the pH was adjusted to 6.0 (Macias, Castellano, Molinillo, 2000) with a solution of $0.1 \mathrm{~N} \mathrm{KOH}$ by using a 
$\mathrm{pH}$ meter. For the germination bioassays, the methodology of Macias et al. (2000) was applied, in which $5.0 \mathrm{~mL}$ of the solution from the treatments was placed in petri dishes $(9.0 \mathrm{~cm}$ in diameter) with Whatman no. 10 filter paper, which were previously placed in an autoclave at $120^{\circ} \mathrm{C}$ for 20 minutes. Soon after, 50 diaspores were sowed and arranged at random over each disk of filter paper, with four repetitions for each solution, according to Brasil (2009). As control, a similar procedure was used but without the extracts. Petri dishes containing the diaspores were kept in a germination chamber (BOD) under light conditions (160 W), relative humidity ( $\pm 80 \%)$, and constant temperature, according to Brasil (2009) (lettuce kept at $25^{\circ} \mathrm{C}$ with constant internal light). Evaluation of the germination was carried out daily, every 12 hours; the criterion was a radicular protrusion with a minimum length of $2.0 \mathrm{~mm}$. The experiment was ended when the germination measurement was insignificant for three days in a row. For the growth bioassays, the methodology described by Barnes et al. (1987) and Macias et al. (2000) was used. First, the seeds were germinated in petri dishes with filter paper dampened with $5.0 \mathrm{~mL}$ of distilled water. After germination, and with the criterion of a radicular protrusion with a minimum length of $2.0 \mathrm{~mm}, 80$ seedlings (four repetitions with 20) were selected for each treatment. These were transferred to petri dishes with the treatment solution through a similar procedure to that described in the germination bioassays. After three days of the radicular protrusion, the root and hypocotyl elongations were measured (ten seedlings for each dish) with a millimeter graph paper. The roots and hypocotyls were then washed and later dried in a stove at $60{ }^{\circ} \mathrm{C}$ until a constant weight was achieved to obtain the dry weight.

\section{Analysis of the mitotic index (MI)}

To determine the mitotic index, $2 \mathrm{~cm}$ of primary root from each seedling was collected from the distal extremity, immersed in Farmer's solution (3:1 ethanol/ glacial acetic acid) (Jensen, 1962) for two hours at $25^{\circ} \mathrm{C}$, and then transferred into a solution of $70 \%$ alcohol and stored at $8{ }^{\circ} \mathrm{C}$. The tips of the roots were treated according to Oliveira et al. (1996) and dyed with toluidine blue to determine the mitotic index. The dyed root tips were cut, initial $2.0 \mathrm{~mm}$, on the microscope blade and then pressed under the filter paper to crush the apex and extract excess dye. The material was observed under a standard optical microscope with 1000x magnification, and the number of cells in each phase of mitosis (prophase, metaphase, anaphase, and telophase) was counted. The blades were triple evaluated.

\section{Evaluation of enzymes related to the defense proteins}

For the analysis, $2.0 \mathrm{~g}$ of fresh lettuce material was crushed in gral with liquid nitrogen. The resulting powder was homogenized with $50 \mathrm{mM}$ sodium phosphate buffer (pH 7.0) containing $2 \mathrm{mM}$ EDTA and 1.0\% PVP. The supernatant was collected and used as crude extract at the described dosages; the precipitate was discarded (Marques, Xavier Filho, 1991). The extracts were conditioned at $-18^{\circ} \mathrm{C}$ at the Laboratório de Farmacotécnica, UFPR, until analysis.

The quantity of total proteins was measured by using the method described by Bradford (1996). The protein concentration of the extracts was determined by comparison with a standard curve of bovine serum albumin (BSA) and measured by spectrophotometry at 594nm absorbance.

The SOD activity was determined through the method of Gupta et al. (1993), by using a reaction mixture containing the enzymatic extract and adding $50 \mathrm{mM}$ potassium phosphate ( $\mathrm{pH} 7.8$ ), 9.9 mM L-methionine, $57 \mu \mathrm{M}$ nitrotetrazolium blue (NBT), and $44 \mathrm{mM}$ riboflavin buffer. After 20 minutes of the portion, the absorbance at $560 \mathrm{~nm}$ was measured, and the SOD activity in unit SOD. ${ }^{-1} \mathrm{MF}$ was recorded. In this assay, a SOD unit was defined as the quantity of enzyme necessary to inhibit $50 \%$ the photoreduction of nitrotetrazolium blue.

The POD activity was determined according to the method by Pütter (1974). The reaction system contained a mixture of $0.1 \mathrm{M}$ sodium phosphate ( $\mathrm{pH} 7.0$ ), $0.1 \mathrm{M}$ pyrogallol, and $0.1 \mathrm{M} \mathrm{H}_{2} \mathrm{O}_{2}$. The absorbance of the mixture at $470 \mathrm{~nm}$ was measured. The specific activity (POD

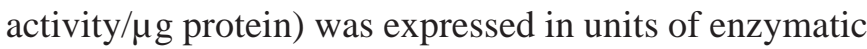
activity (UEA), in which one unit corresponds, randomly, to a difference of 0.001 in protein absorbance/minute/ $\mu \mathrm{g}$ (Gray et al., 1996).

The CAT assay was measured by adding $1 \mathrm{M} \mathrm{H}_{2} \mathrm{O}_{2}$ to a reaction mixture containing $50 \mathrm{mM}$ sodium phosphate (pH 6.0) and enzymatic extract. The decrease in $\mathrm{H}_{2} \mathrm{O}_{2}$ was monitored by the absorbance at $240 \mathrm{~nm}$; the absorbance difference $(\triangle \mathrm{A} 240 \mathrm{~nm})$, obtained by linear regression, was divided by the coefficient of molar extinction from $39.4 \mathrm{M}^{-1} \cdot \mathrm{cm}^{-1}$ of $\mathrm{H}_{2} \mathrm{O}_{2}$ (Aebi, 1984). The CAT activity was expressed in units of enzyme activity.FM (fresh material).

The APX activity was determined according to the method of Amako et al. (1994). The reaction mixture contained $50 \mathrm{mM}$ potassium phosphate $(\mathrm{pH} 7.0), 1 \mathrm{mM}$ hydrogen peroxide, $0.5 \mathrm{mM}$ ascorbic acid, $0.1 \mathrm{mM}$ EDTA, and enzymatic extract buffer. The absorbance of the mixture was measured at $290 \mathrm{~nm}$. The rate of ascorbate 
oxidation was evaluated by monitoring the absorbance decrease, and the APX activity was expressed in units of enzyme activity.FM (fresh material).

The PPO activity was determined according to the method of Duangmal and Owusu Apenten (1999), which measures the conversion of catechol in quinone. The substract used was compound by $20 \mathrm{mM}$ catechol in $100 \mathrm{mM}$ sodium phosphate buffer (pH 6.8). For the reaction, which was done at $30^{\circ} \mathrm{C}$, the mixture was added to the enzymatic extract, and its absorbance was measured at $420 \mathrm{~nm}$ with a spectrophotometer. The results were expressed in units of enzyme activity.FM (fresh material).

To determine the $\alpha$-amylase activity, the extract was placed in a double boiler at $70{ }^{\circ} \mathrm{C}$ for 20 minutes, added to a solution of $1.0 \%$ amide and phosphate buffer, and then incubated at $30{ }^{\circ} \mathrm{C}$ for 5 minutes. After, a solution of lugol $1.0 \% \mathrm{~mL}$ and the measurement was achieved in a spectrophotometer at $620 \mathrm{~nm}(A O A C, 1965)$. The results were expressed in $\mu \mathrm{g} \mathrm{min}{ }^{-1} \cdot \mathrm{g}^{-1} \mathrm{MF}$ of hydrolyzed starch.

The chlorophyll content was determined after crushing of the aerial parts of the seedlings in gral and extraction with DMSO (Cayon et al., 1990). The solution absorbances were measured with a spectrophotometer at 645 and $663 \mathrm{~nm}$ wavelengths, after which the chlorophyll a, chlorophyll b, and total chlorophyll contents were calculated (Arnon, 1949). The potential respiration of the root cells from the lettuce seedlings was evaluated by the reduction of triphenyl tetrazolium chloride (TTC) through the activity of the dehydrogenase enzymes and with the emergence of formazan. To evaluate this characteristic, the roots were first cut at $1 \mathrm{~cm}$ from the root cap, and then all their masses were taken and transferred to test tubes containing a $0.6 \%(\mathrm{p} / \mathrm{v})$ TTC solution in $0.05 \mathrm{M}$ phosphate buffer (pH 7.0). The test tubes were kept under vacuum in desiccators for 2 hours and then placed in a double boiler at $30{ }^{\circ} \mathrm{C}$ for 15 hours.

At the end of this period, the TTC solutions were drained from the test tubes, and the roots were washed once in distilled water. The test tubes containing the roots were again transferred to a double boiler with boiling water $\left( \pm 100{ }^{\circ} \mathrm{C}\right)$, into which $95 \%$ (V/V) ethanol was added. After 10 minutes, the obtained ethanolic solutions were drained into other test tubes. After cooling at room temperature, $10 \mathrm{~mL}$ of $95 \%(\mathrm{~V} / \mathrm{V})$ ethanol was added to each solution. The absorbances of these ethanolic solutions were measured with a spectrophotometer at $530 \mathrm{~nm}$ wavelength (Steponkus, Lanphear, 1967).

\section{Statistical analysis}

This study used a randomized design involving four simple assays, FH, FM, and FCL of C. sinensis, with four treatments $(0,250,500$, and $1000 \mathrm{mg} / \mathrm{L})$, in four repetitions for the germination and growth bioassays and three repetitions for the mitotic index and enzymatic tests. Each portion consisted of 50 diaspores for the germination and 10 for the root and hypocotyl growth. The germinability (\%G) was calculated according to the methodology described by Labouriau (1983) and the germination speed index (GSI) by Maguire (1962), as cited by Ferreira and Borghetti (2006).

The data were submitted to variance analysis, and when the treatment effects were significant $(p<0.05)$ in relation to the control, the means were compared by using Tukey's test. All results were analyzed at the significance level of $\alpha=5 \%$.

\section{RESULTS AND DISCUSSION}

Co-injection analysis with standards in gas chromatography led to the identification of methyl esters in synthesized fatty acids from the transesterification with methanol, from the respective methyl esters isolated from the hexane fraction: palmitic, estearic, oleic, linoleic and $\alpha$-linoleic acids (C 18:3) (Figure 1).

In the fixed oils analysis, the oleic, linoleic, and $\alpha$-linoleic unsaturated fatty acids eluted at a higher period of retention and in meaningful quantities, being the most part polyunsaturated fatty acids. These results indicate that the residue could be treated as a functional food that could be important in the health industry, considering that unsaturated compounds represent about $80 \%$ of the oil composition of the Citrus sinensis seed, and $61 \%$ of those compounds are polyunsaturated (Table I).

This characteristic assists the commercial use of residues from the fruits because materials rich in monounsaturated and polyunsaturated fatty acids are of great importance to industries that are seeking alternative ingredients for healthier products (Nascimento et al., 2008).

In relation to the germination and growth bioassays, the analysis of the allelopathic effects of Citrus sinensis fractions indicated that the intensity of the effects varied with the evaluated fractions and the concentrations used as indicators. Regarding the germination speed, all fractions were observed to have delayed germination, which caused a reduction in the lettuce germinability (Table II). FCL and FM fractions at 250, 500, and $1000 \mu \mathrm{g} \cdot \mathrm{mL}^{-1}$ concentrations caused a delay in germination with values higher than $50 \%$. The results for the chloroform and ethanolic fractions were $\pm 55 \%$ and $\pm 70 \%$, respectively. For the germination, the methanolic fraction was found to inhibit the final 


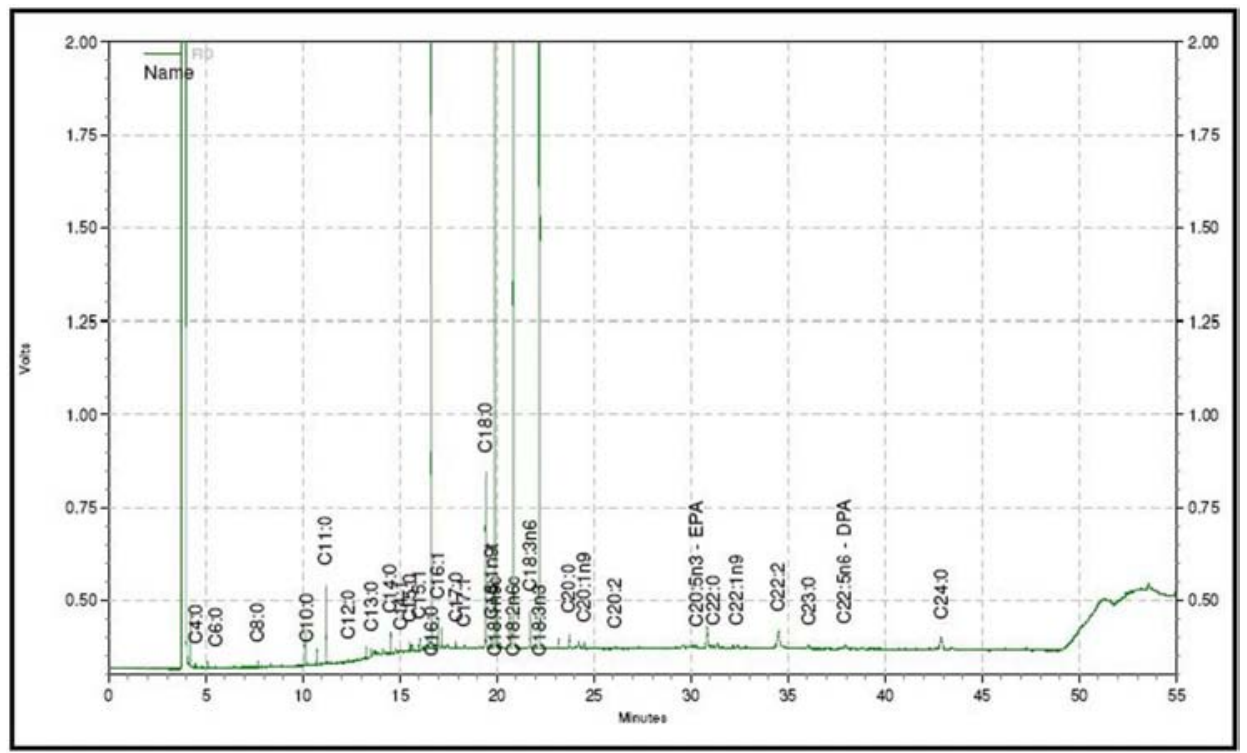

FIGURE 1 - Chromatogram (GC) obtained from the hexane extract of Citrus sinensis, seeds, showing fatty esters in the oil.

TABLE I - Fatty acids with higher concentrations (\%) in the seed oil of Citrus sinensis as analyzed by peak area

\begin{tabular}{lcc}
\hline Fatty acid Name & $\begin{array}{c}\text { Retention time in } \\
\text { the chromatogram } \\
\text { (min) }\end{array}$ & $\begin{array}{c}\text { Concentration } \\
\text { (\%) }\end{array}$ \\
\hline Palmitic acid & $16: 61$ & 9.7 \\
Stearic Acid & $19: 42$ & 3.3 \\
Oleic Acid & $19: 89$ & 17.8 \\
Linoleic Acid & $20: 85$ & 36.3 \\
$\alpha$-linolenic Acid & $22: 19$ & 25.3 \\
\hline
\end{tabular}

percentage of germinated seeds, causing $93.5 \%$ of the reductions in the highest assayed concentration compared with the control (Table II).

Studies with vegetable oils were evaluated for verifying the inhibition of the seeds germination and some of them were rich in saturated fatty acids with long chain, and the palmitic and oleic acids were distinguished. Some reports in the literature have identified oleic, myristic, stearic, palmitic, and linoleic acids, as well as other longchain fatty acids, as allelophatic agents. The $\alpha$-eristic and palmitic acids are considered the most potent inhibitors of sorghum germination, and their inhibitory capacity is

TABLE II - Germination rate index (GSI) and germination percentage (G\%) of lettuce exposed to different concentrations of hexane (FH), chloroform (FCL), and methanol (FM) fractions of Citrus sinensis

\begin{tabular}{|c|c|c|c|}
\hline \multicolumn{4}{|c|}{ Germination Speed Index (GSI) } \\
\hline Treatment & $250 \mathrm{mg} / \mathrm{L}$ & $500 \mathrm{mg} / \mathrm{L}$ & $1000 \mathrm{mg} / \mathrm{L}$ \\
\hline \multicolumn{4}{|c|}{ Control: $24,54 \pm(0,41)$} \\
\hline $\mathrm{FH}$ & $16,20 \pm(0,73)^{*}$ & $12,50 \pm(0,62)^{*}$ & $16,60 \pm(0,17)^{*}$ \\
\hline FCL & $15,94 \pm(0,49)^{*}$ & $14,2 \pm(0,51)^{*}$ & $10,8 \pm(0,71)^{*}$ \\
\hline FM & $13,96 \pm(0,40)^{*}$ & $10,47 \pm(0,15)^{*}$ & $7,19 \pm(0,25)^{*}$ \\
\hline \multicolumn{4}{|c|}{ Germination percentage (G\%) } \\
\hline Treatment & $250 \mathrm{mg} / \mathrm{L}$ & $500 \mathrm{mg} / \mathrm{L}$ & $1000 \mathrm{mg} / \mathrm{L}$ \\
\hline \multicolumn{4}{|c|}{ Control: $99,5 \pm(1,00)$} \\
\hline $\mathrm{FH}$ & $86,5 \pm(3,00)^{*}$ & $74,5 \pm(3,00)^{*}$ & $46,5 \pm(1,15)^{*}$ \\
\hline FCL & $79,5 \pm(1,91)^{*}$ & $75,0 \pm(2,58)^{*}$ & $52,5 \pm(4,72)^{*}$ \\
\hline FM & $93,5 \pm(2,51)^{*}$ & $80,5 \pm(1,00)^{*}$ & $83,0 \pm(1,91)^{*}$ \\
\hline
\end{tabular}

* Tukey's test showed that the mean treatment differed significantly $(\mathrm{p}<0.05)$ from the average control. ${ }^{\text {ns }}$ The average treatment did not differ significantly from the control. 

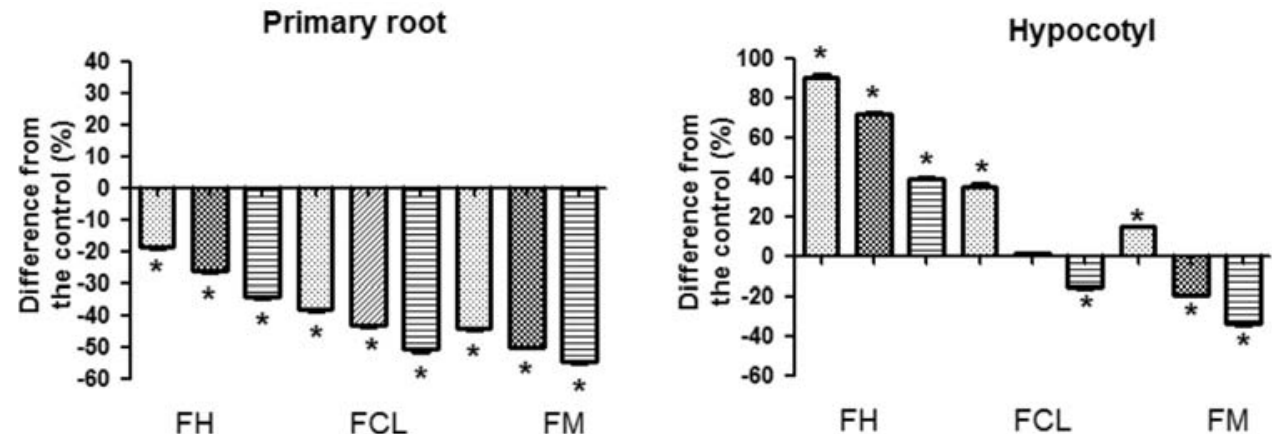

\section{圈 Control $\square 250 \mu \mathrm{g} / \mathrm{mL}^{-1} \square 500 \mu \mathrm{g} / \mathrm{mL}^{-1}$ 貝 $1000 \mu \mathrm{g} / \mathrm{mL}^{-1}$}

FIGURE 2 - Average growth of the hypocotyl and root dry mass of lettuce seedlings subjected to hexane (FH), chloroform (FCL), and methanol (FM) fractions of Citrus sinensis. Data are expressed as percentages relative to control.

inversely proportional to the size of the carbon acid chain (Xuan, Tsuzuki, 2004; Edney, Rizvi, 1996; Marambe, Nagaoka, Ando, 1993; Rice, 1984).

Regarding the growth evaluation, the fractions were found to cause a decrease in seedling size when the highest assayed concentrations (Figures 2 and 3) of primary roots and hypocotyls were analyzed. The most marked effects were observed in FM, with $\pm 50 \%$ and $\pm 55 \%$ for primary roots and $\pm 19 \%$ and $\pm 33 \%$ for hypocotyls at 500 and $1000 \mu \mathrm{g} / \mathrm{mL}^{-1}$ concentrations, respectively (Figure 2). For the dry weight content, no significant reductions were observed in any of the assayed fractions, indicating that the evaluated fractions did not cause a decrease in vegetal biomass in the studied species, which may be justified by the thickening of the primary roots and hypocotyls (Figure 3).

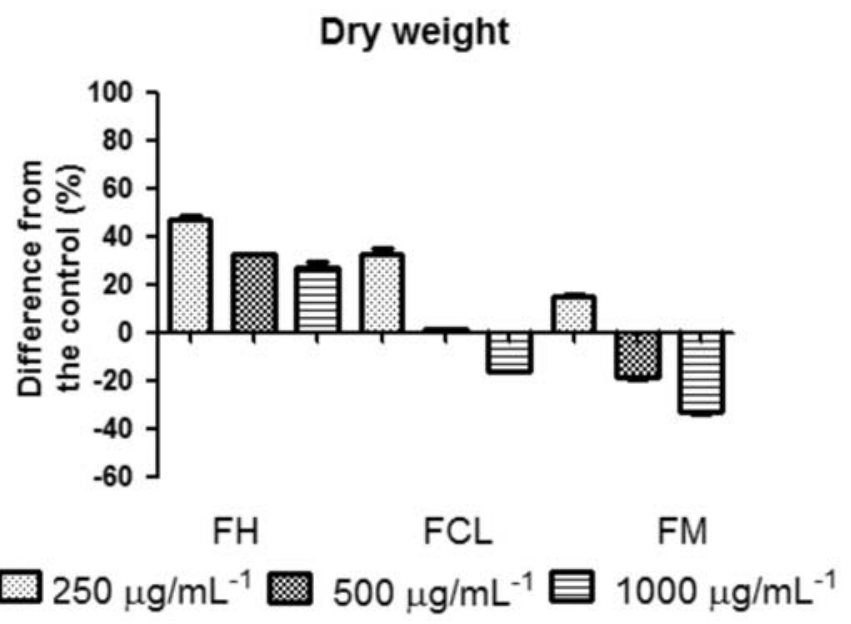

FIGURE 3 - Decrease in the dry weight of lettuce seedlings subjected to hexane (FH), chloroform (FCL), and methanol fractions (FM) of Citrus sinensis. Data are expressed as percentages relative to control.
FCL at $250 \mu \mathrm{g} \cdot \mathrm{mL}^{-1}$ concentration showed the stimulation of the hypocotyls and dry weight; no allelopathic effect was observed at $500 \mathrm{mg} / \mathrm{mL}$ concentration. It is possible that the stimulus occurred in the fraction because a low concentration causes the effect known as hormesis. Liu et al. (2003) acknowledged that when bioassay techniques are used to study the effects of allelochemicals on plant processes, the processes are generally observed to be stimulated at low allelochemical concentrations and inhibited as the concentrations increase.

These results suggest a possible phototoxic effect of linoleic acid on L. sativa. Quintana et al. (2009) showed that linoleic acid was phytotoxic in L. sativa and that the toxicity of fatty acids increases with an increase in double bonds. The phytotoxic properties of fatty acids are well known and understood. The allelopathic properties of long-chain fatty acids on algae have been reported previously by Song et al. (2004), and fatty acids, among other compounds, have been identified as putative allelochemicals.

Regarding morphologic changes, all the fractions were found to cause changes in some evaluated parameters, such as an increase or decrease of hairs in the piliferous zone or of oxidation in the root cap region. The $1000 \mu \mathrm{g} . \mathrm{mL}^{-1}$ concentration of FH and FCL (Figure 4) caused secondary root and meristematic callus formation in the region of the piliferous zone; this process may be associated with an increase in ethyl synthesis by the primary roots, causing morphologic changes (Taiz, Zeiger, 2004). The $250 \mu \mathrm{g} . \mathrm{mL}^{-1}$ concentration of FM (Figure $4 \mathrm{H}$ ) caused an increase of hairs in the piliferous zone, which may be related to a deficiency in water absorption by the seedling; the increase of hairs served as a mechanism for improving the absorption (Larcher, 2000). 


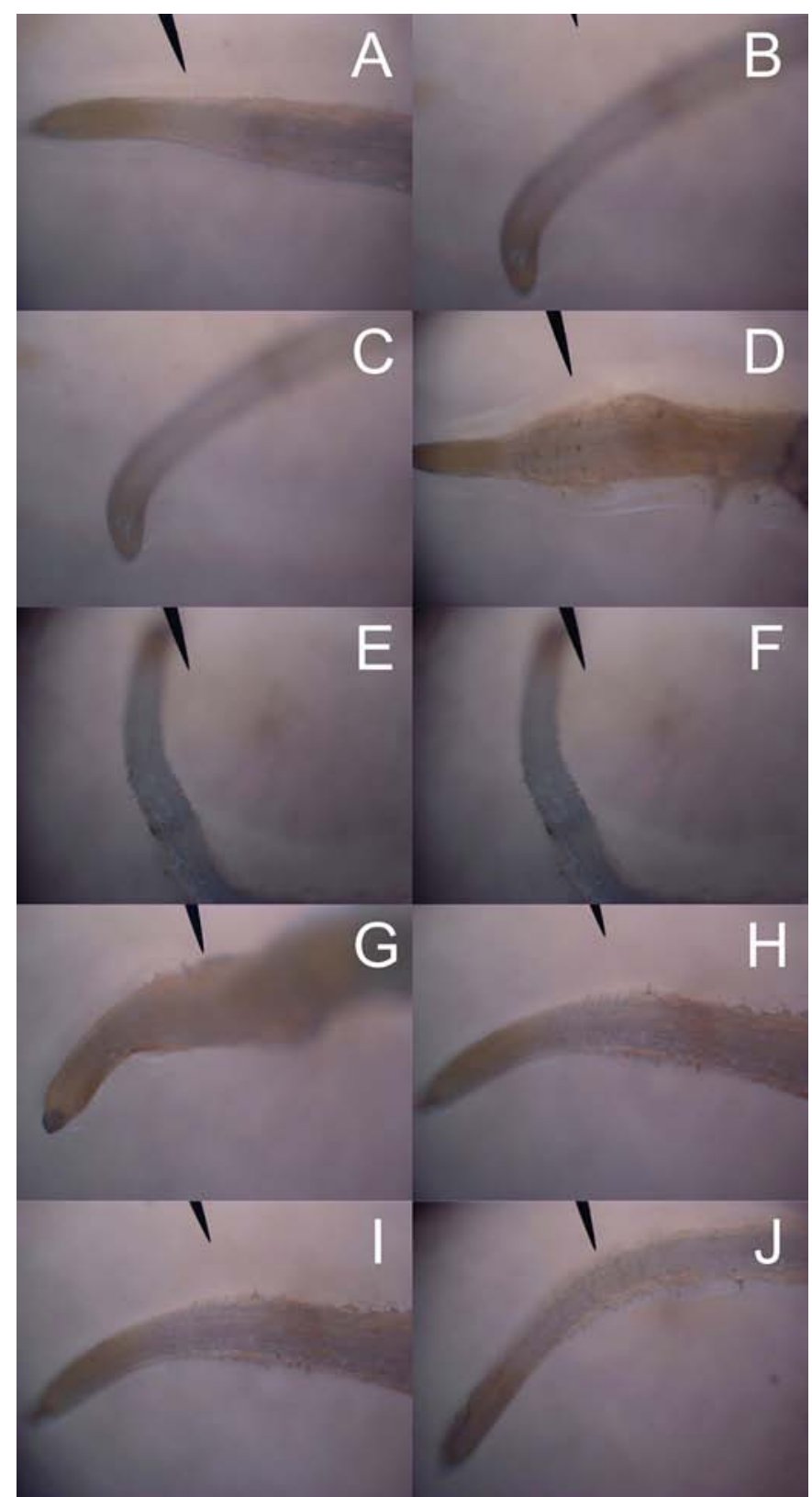

FIGURE 4 - Pattern changes in the morphologic meristematic region (piliferous zone and hood) of Lactuca sativa seedlings subjected to (A) control with distilled water, (B, C, D) hexane fraction, (E, F, G) chloroform fraction, and (H, I, J) methanol fraction from Citrus sinensis.

Regarding the mitotic rate evaluation, as the concentration of the evaluated fractions increased, the mitotic rate decreased (Figure 5), with the lowest mitotic rate obtained at $1000 \mu \mathrm{g} \cdot \mathrm{mL}^{-1}$ concentration $( \pm 69 \%$ inhibition). When the mitosis frequencies were compared between treatments, the highest values were observed in the prophase and the lowest ones in the other phases, indicating that the fraction concentrations caused a drastic reduction in the mitotic rate; the root growth stopped at the $500 \mu \mathrm{g} . \mathrm{mL}^{-1}$ concentration, mainly in the absence of the telophase. This interference in cell division caused by the extract highlights the negative effect of the extract on the development of the test plant.

At higher concentrations, all extracts caused the inhibition of the mitotic activity. Consistent results were found between inhibition of root growth and decrease in mitotic index (MI) at the highest extract concentrations tested. The MI for treated roots was significantly lower than that for control, indicating alterations in the growth and development of exposed plants as a result of chemical action (Hoshina \& Marin-Morales, 2009).

Peres et al. (2007) suggested that plants, because of their sessile nature, have developed mechanisms that allow them to adjust the cell cycle in response to the environment. Both biotic and abiotic stress stimuli can affect plant growth negatively through the inhibition of the cell cycle machinery. The cell cycle can be affected in several ways. The perception of biotic and abiotic stress signals activates signaling cascades that trigger ion fluxes, kinase cascades, the generation of ROS, and the accumulation of anti-mitogenic hormones, such as abscisic and jasmonic acids. These signaling molecules might stimulate cell-cycle checkpoints, resulting in impaired G1-to-S transition, followed by a decrease in DNA replication and/or delayed entry into mitosis (Peres et al., 2007).

Regardless of the primary mechanisms of allelochemical-induced oxidative stress, our data suggest that the presence of allelochemicals, which cause further oxidative stress, may leave seeds/seedlings more vulnerable to cellular dysfunction and cell death. In agro-ecosystems, allelochemicals with high oxidative stress-inducing potential can be released from cultivated plants or cover crops and cause inhibition of the growth and development of weed species. The identification of these allelochemicals may contribute to the discovery of natural compounds with herbicide potential (Duke et al., 2000; Inderjit, Duke, 2003). In fact, some commercial herbicides are known to cause cellular death by inducing oxidative stress. This is a consequence of either electron flow interference in photo system II (PSII) or inhibition of synthesis of antioxidant compounds, including carotenoids (Kruse et al., 2006).

Regarding the antioxidant balance, a marked increase in the production of POD and CAT enzymes was verified at all concentrations of the used fractions. However, in the analysis of POD activity, the lettuce seedlings were found to be more sensitive to the methanolic and chloroformic fractions at the highest assayed concentrations, with an increase of \pm 13 and $\pm 15 \%$, respectively, suggesting a 

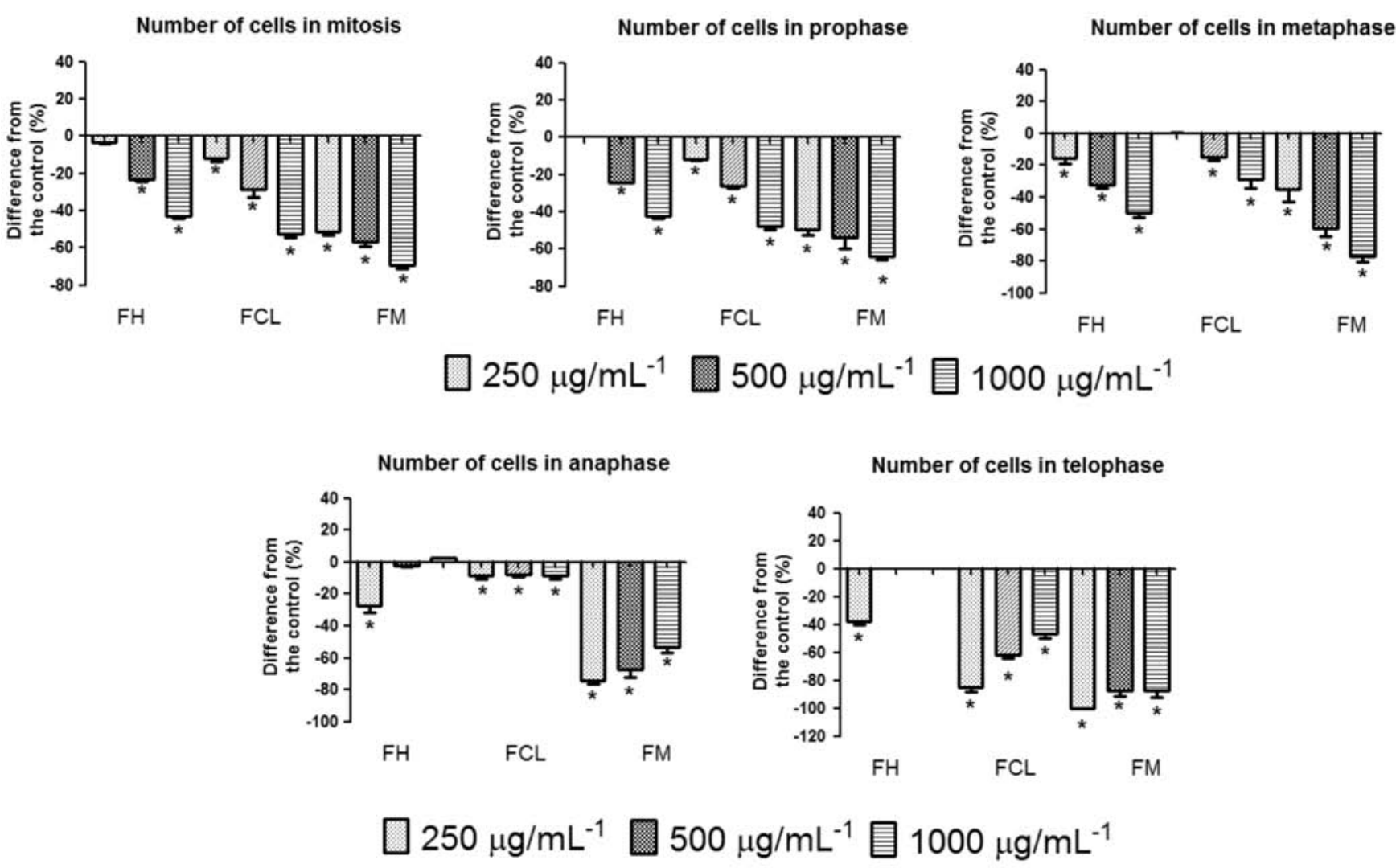

*Statistically different from the control treatment (Tukey Test,
$p<0.05$ ).

FIGURE 5 - Mitotic index of lettuce meristematic root cells exposed to different concentrations of hexane (FH), chloroform (FCL), and methanol (FM) fractions from Citrus sinensis. Data are expressed as percentages relative to control.

possible relation. Regarding CAT activity, the chloroformic fraction presented a higher performance, with an increase of $\pm 20 \%$ at $1000 \mu \mathrm{g} \cdot \mathrm{mL}^{-1}$ concentration (Figure 6).

A similar effect was verified in the production of APX, which was not significant only in the $250 \mu \mathrm{g} . \mathrm{mL}^{-1}$ FH treatment. FM altered the activity of this enzyme, with an observed increase of \pm 34 UEA.mg $^{-1}$ and \pm 39 UEA. $\mathrm{mg}^{-1}$ at the $500 \mu \mathrm{g} \cdot \mathrm{mL}^{-1}$ and $1000 \mu \mathrm{g} \cdot \mathrm{mL}^{-1}$ concentration, respectively, compared with the control. A change in SOD activity was observed, with FCL and FM causing an increase of \pm 9 UEA. $\mathrm{mg}^{-1}$ for both fractions at $1000 \mu \mathrm{g} . \mathrm{mL}^{-1}$ concentration. Regarding the PPO activity for FCL and FM at $1000 \mu \mathrm{g} \cdot \mathrm{mL}^{-1}$ concentration, stimuli of 63 UEA.mg $^{-1}$ and 74 UEA.mg ${ }^{-1}$. FM were observed, which were statistically significant when compared with the control (Figure 6).

Regarding the energetic metabolism ( $\alpha$-amylase), an increase in enzymatic production was observed in all fractions and at the highest assayed concentrations, when compared with the control; the methanol fraction did not present any activity at the lowest concentration.
Regarding the total protein content, an increment was observed in all evaluated fractions, with only the $500 \mu \mathrm{g} . \mathrm{mL}^{-1} \mathrm{FH}$ concentration showing a nonsignificant increase relative to the control (Fig. 7). The $1000 \mu \mathrm{g} . \mathrm{mL}^{-1} \mathrm{FCL}$ and FM concentrations caused an increase of 222 and 234 UEA.mg $^{-1}$, respectively, which was related to the high level of the evaluated enzymes (Figure 7).

The occurrence of SOD, CAT, and POD activities in seedlings, along with the significant respiration, suggests that the production of ROS is initiated as soon as mitochondrial respiration is reestablished during seed imbibition. Respiration accounts for the oxygen that is converted into superoxide and $\mathrm{H}_{2} \mathrm{O}_{2}$ (Puntarullo et al., 1988) or used by the mitochondrial alternative oxidase (AOX) and other cytosolic or membrane-bound oxidases, including lipoxygenases. Although the relative contribution of each process to respiration and total chlorophyll cannot be inferred from our data, all these processes have been previously shown to be stimulated in oxidative stress conditions (Siedow, Moore, 1991; Baker, 

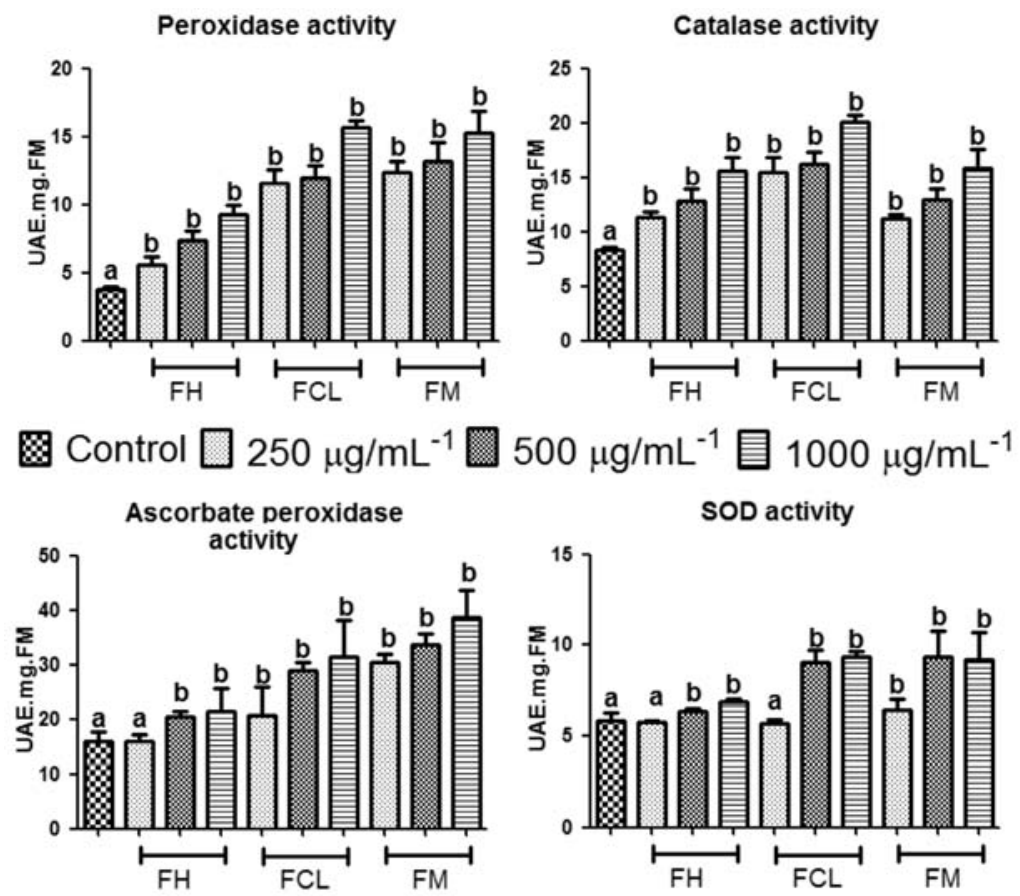

囚 Control $\square 250 \mu \mathrm{g} / \mathrm{mL}^{-1} \square 500 \mu \mathrm{g} / \mathrm{mL}^{-1}$ 目 $1000 \mu \mathrm{g} / \mathrm{mL}^{-1}$

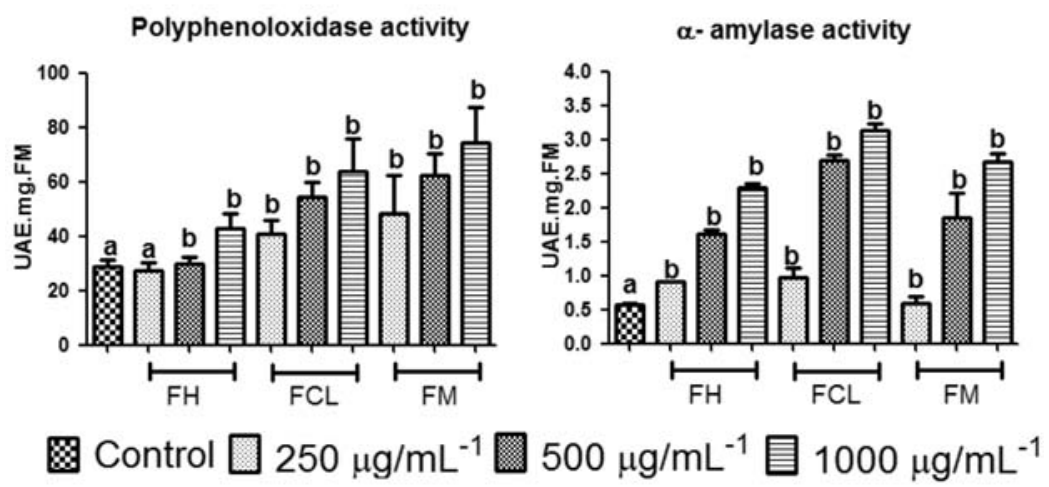

FIGURE 6 - Peroxidase, catalase, ascorbate peroxidase, superoxide dismutase, $\alpha$-amylase, and polyphenol oxidase activity in lettuce seedlings subjected to hexane (FH), chloroform (FCL), and methanolic (FM) fractions of Citrus sinensis. Data are expressed as percentages relative to control.

Orlandi, 1995; Thaler, 1999; Porta, Rocha-Sosa, 2002; Blokhin, Virolainen, Fagerstedt, 2003).

After the completion of germination, there was a distinct pattern of change in the activities of antioxidant enzymes in hypocotyls and primary roots. The activity levels of SOD, CAT, APX, and POD in seedlings had increased its activities period, possibly reflecting a further increase in ROS production. This was probably due to the higher oxygen availability for primary roots in comparison with cotyledons, as Wojtyla et al. (2006) observed in pea seeds. Those authors verified an increase in the concentration of free radicals in embryo axes after radicle protrusion, but they reported no significant changes in cotyledons. Goodman et al. (1986) also reported a large and rapid change in free radical levels in roots as a direct consequence of the oxygen content in the surrounding atmosphere.

A comparison of the activities of the assayed enzymes indicated that SOD and CAT were probably the main antioxidant enzymes involved in the scavenging of ROS for Ipomoea triloba during germination (Pergo, Ishii-Iwamoto, 2011). The species also contains accessory enzymes that neutralize $\mathrm{H}_{2} \mathrm{O}_{2}$, such as the PODs. PODs exist in a large number of isoenzymatic forms and are implicated in a broad range of enzymatic reactions (Noctor, Foyer, 1998); a correlation between APX activity and levels of ascorbic acid was shown by Wojtyla et al. (2006). Thus, ascorbate could play a role in nonenzymatic 


\section{Total proteins}

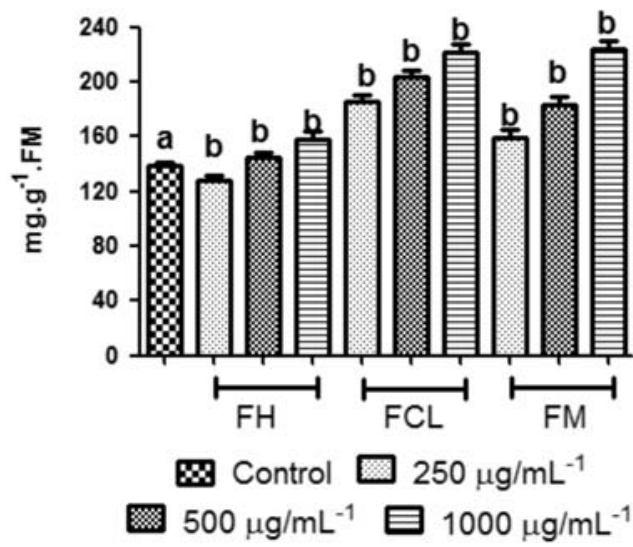

FIGURE 7 - Total protein content of lettuce seedlings subjected to hexane (FH), chloroform (FCL), and methanolic (FM) fractions of Citrus sinensis.

antioxidant defense systems in primary roots of $I$. sativa physiological processes (Passardi et al., 2005). PODs bind to cell wall polymers by ionic or covalent interactions, and these bonds are believed to participate in lignin biosynthesis and the formation of cross-linking in the cell wall (Müsel et al., 1997; Quiroga et al., 2000). Guaiacolspecific PODs have been used as indicators of oxidative stress (Almagro et al., 2009).

The above-mentioned effects may have contributed to the decrease in energetic consumption during germination, leading to an increase of total proteins. The germination process of the seeds leads to enzymatic unchaining, which is capable of developing nutritive reserves to nourish the embryonic axis. Whereas starch is one of the stock molecules in the plant kingdom, $\alpha$-amylase is one of the hydrolytic enzymes that cleaves to starch, providing specific energy for plant growth (Buckeridge et al., 2004).

Regarding the chlorophyll content, the chloroformic and methanolic fractions caused a significant reduction in the chlorophyll content of the lettuce at all evaluated concentrations (Figure 8). The highest concentrations reduced the chlorophyll in the studied leaves, causing a decrease in photosynthesis activity, with a reduction of $\pm 14 \mathrm{mg} . \mathrm{L}^{-1}$ and $\pm 15 \mathrm{mg} . \mathrm{L}^{-1}$ at the $1000 \mathrm{mg} . \mathrm{L}^{-1}$ concentration.

In the respiratory process, FCL and FM caused greater reduction only at $1000 \mathrm{mg} / \mathrm{L}$ concentration, with 1.524 and 1.116 UEA.mg.MF decreases in formazan synthesis. FH led to respiratory increases in roots throughout the highest concentrations compared with the control (Figure 8).

These results reveal that respiration and total chlorophyll in seedlings of L. sativa appear shortly after the seed imbibition period, as indicated by the considerable respiratory activity. The respiratory activity of primary roots is gradually decreased during the growth period. Considering that the total chlorophyll activity in primary roots also progressively decreased, these findings could represent a decrease in ATP demand after completion of germination. A similar pattern of changes in respiratory activity has been observed in two other weed species, Bidens pilosa L. (Pergo, Ishii-Iwamoto, 2011) and Euphorbia heterophylla L. (Kern et al., 2009).

Several authors have noted that some classes of allelochemicals inhibit photosynthesis by inducing changes in the chlorophyll content of the receptor plants (Chou, 1999; Baziramakenga, Simard, Leroux, 1994; Blum, Rebbeck, 1989; Einhellig, Rasmussen, 1979; Einhellig et al., 1970). The chlorotic appearance of the plants could be a symptom of the degradation of chlorophyll or the inhibition of its synthesis, which could prevent Mg-porphyrin formation (Einhellig, 1986). In both cases, these effects are similar to the role of herbicides, such as pyridazinones and imidazolinones (Cayon et al., 1990; Duke, 1985).

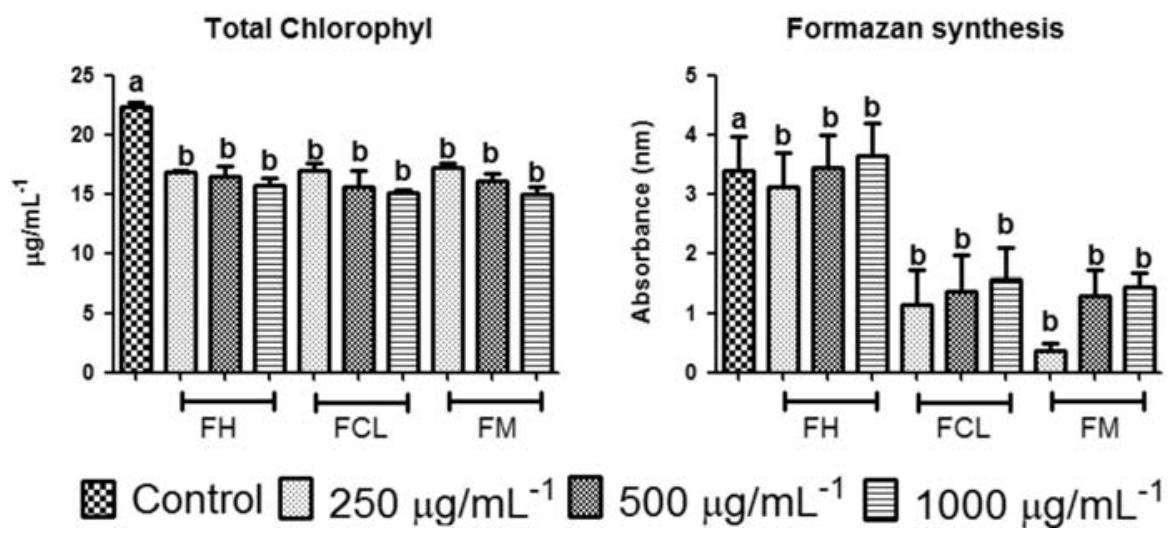

FIGURE 8 - Chrorophyll content and respiration in roots of lettuce seedlings subjected to hexane (FH), chloroform (FCL) and methanolic (FM) fractions of Citrus sinenis. 
The results obtained in this study show the potential application of $C$. sinensis residues as herbicides and are comparable with the findings presented by Kato-Noguchi and Tanaka (2004), in which Citrus junos residues inhibited the growth of roots and sprouts of alfafa (Medicago sativa L.), watercress (Lepidium sativum L.), crabgrass (Digitaria sanguinalis $L$.), lettuce (Lactuca sativa L.), Timothy (Pheleum pretense L.), and ryegrass (Lolium multiflorum Lam.). Therefore, all these residues can be used for weed management. An interesting result observed by KatoNoguchi and Tanaka (2004) was that there was no plant growth near Citrus aurantium plantations, which could indicate the presence of allelophatic mechanisms.

The occurrence of SOD, CAT, and POD activities in seedlings, along with the significant alteration in respiration, suggests that production of ROS is initiated as soon as mitochondrial respiration resumes during the seed imbibition. Although the relative contribution of each process to respiration is not clear from our data, all these processes are stimulated in oxidative stress conditions (Silva et al., 2014).

Plant development has decisive stages that are very vulnerable, such as seed germination, and it is important to take these stages into account when seedling growth is studied. Seed germination is the process by which the plant embryo resumes growth after a period of quiescence. Under favorable conditions, the rapid growth of the embryo culminates in rupture of covering layers and emergence of the radicle, which is considered the completion of germination. At this stage, the fate of individual embryo cells, whether they reenter the cell cycle or remain in arrested state, is decisive in determining seedling formation. The development and functionality of the plant depend on the capacities of embryo cells to restart division and differentiate into new cells (Barrôco et al., 2005).

\section{CONCLUSION}

The results of this study showed that the oils extracted from Citrus sinensis seeds are a rich source of unsaturated fatty acids with important industrial uses, particularly as possible allelopathic compounds. Because Brazil is one of the biggest producers of Citrus in the world, and Citrus seeds are generally discarded as agroindustrial residues, the results presented here suggest that these residues could be used as a potential allelopathic commodity for weed growth management in both small and large crops cultivated in Brazil.

\section{REFERENCES}

ADAMS, R.P. Identification of essential oil components by gas chromatography and mass spectrometry. 4. ed. Illinois, USA: Allured Publ. Corp. Carol Stream, 1995. 469 p.

AEBI, H. Catalase in vitro. Methods Enzymol., v.105, n.1, p.121-126, 1984.

ALMAGRO, L.; GÓMEZ-ROS, L.V.; BELCHI-NAVARRO, S.; BRU, R.; ROS-BARCELÓ, A.; PEDREÑO, M.A. Class III peroxidases in plant defence reactions. J. Exp. Bot., v.60, n.2, p.377-390, 2009.

AMAKO, K.; CHEN, G.X.; ASADA, K. Separte assays specific for ascorbate perosidase and guaiacaol peroxidase and for chloroplastidic and cytosolic isozymes of ascorbate peroxidase in plants. Plant Cell Physiol., v.35, n.3, p.497504, 1994.

ARNON, D.I. Copper enzymes in isolated chloroplasts, polyphenoxidase in beta vulgaris. Plant Physiol., v.24, n.1, p.1-15, 1949.

ASSOCIATION OF OFFICIAL AGRICULTURAL CHEMISTS. AOAC. Official methods of analysis. 10.ed. Washington, DC: Editorial Board, 1965. 957 p.

BAKER, C.J.; ORLANDI, E.W. Active oxygen in plant pathogenesis. Annu. Rev. Phytopathol., v.33, p.299-321, 1995.

BARNES, J.P.; PUTNAM, A.R.; ZBURKE, B.A.; AASSEN, A.J. Isolation and characterization of allelochemicals in rye herbage. Phytochemistry, v.26, n.5, p.1385-1390, 1987.

BARRÔCO, R.M.; VANPOUCKE, K.; BERGERVOET, J.H.W.; DE VEYLDER, L.; GROOT, S.P.C.; INZÉ, D.; ENGLER, G. The role of the cell cycle machinery in resumption of postembryonic development. Plant Physiol., v.137, n.1, p.127-140, 2005.

BAZIRAMAKENGA, R., SIMARD, R.R.; LEROUX, G. D. Effects of benzoic and cinnamic acids on growth, mineral composition and chlorophyl content of soybean. J. Chem. Ecol., v.20, n.11, p.2821-2833, 1994.

BLOKHIN, A.O.; VIROLAINEN, E.; FAGERSTEDT, K.V. Antioxidants, oxidative damage and oxygen deprivation stress: a review. Ann. Bot., v.91, n.2, p.179-194, 2003. 
BLUM, U.; REBBECK, J. Inhibition and recover of cucumber roots given multiple treatments of ferulic acid in nutrient culture. J. Chem. Ecol., v.15, n.3, p.917-928, 1989.

BRADFORD, M.M. A rapid e sensitive method for the quantitation of microgram quantities of protein utilizing the principle of protein-dye binding. Anal. Biochem. v. 72, n.1-2, p.248-254, 1996.

BRASIL. Ministério da Agricultura e Reforma Agrária. Secretaria Nacional de Defesa Agropecuária. Departamento Nacional de Defesa Vegetal. Coordenação de Laboratório Vegetal. Regras para análise de sementes. Brasília, DF, 2009. 395 p.

BUCKERIDGE, M.S.; SANTOS H.P.; TINÉ, M.A.S.; ADAIR, M.P.M. Mobilização de reservas. In: FERREIRA, A.G; BORGHETTI, F. (Eds). Germinação: Do básico ao aplicado. Porto Alegre: Artmed, 2004. p. 163-185.

CAYON, D.G.; LOPES, N.L.; OLIVA, M.A.; SILVA, J.F. Teores de clorofila e proteína bruta em soja (Glycine max (L.) Merril) tratada com imazaquin. Braz. J. Plant Physiol., v.2, n.3, p.33-40, 1990.

CHEN, M. S. Inducible direct plant defence against insect herbivores: A review. Insect Sci., v.15, n.1, p.101-114, 2008.

CHOU, C.H. Roles of allelopathy in plant biodiversity and sustainable agriculture. Crit. Rev. Plant Sci. v. 18, n.5, p.609-636, 1999.

DAYAN, F.E.; ROMAGNI, J.G.; DUKE, S.O. Investigating the mode of action of natural phytotoxins. J. Chem. Ecol., v.26, n.9, p.2079-2093, 2000.

DE WIT, P.J. How plants recognize pathogens and defend themselves. Cell Mol. Life Sci., v.64, n.21, p.2726-2732, 2007.

DI BELLA, G.; LO TURCO, V.; RANDO, R.; ARENA, G.; POLLICINO, D.; LUPPINO, R.R.; DUGO, G. Pesticide and plasticizer residues in citrus essential oils from different countries. Nat. Prod. Commun., v. 5, n.8, p.1325-1328, 2010.

DING, L.; JING, H.; QIN, B.; QI, L.; LI, J.; WANG, T.; LIU, G. Regulation of cell division and growth in roots of Lactuca sativa L. seedlings by the entkaurene diterpenoid rabdosin B. J. Chem. Ecol., v.36, n.5, p.553-563, 2010.
DUANGMAL, K.; OWUSU APENTEN, R.K.. A comparative study of polyphenoloxidases from taro (Colocasia esculenta) and potato (Solanum tuberosum var. Romano). Food Chem., v.64, n.3, p.351-359, 1999.

DUKE, S.O. Effects of herbicide on nonphotosynthetic biosynthetic process. In: DUKE, S.O. (Ed). Weed Physiology. Boca Raton USA: CRC Press, 1985. p. 91-112.

DUKE, S.O.; DAYAN, F.E.; ROMAGNI, J.G.; RIMANDO, A.M. Natural products as sources of herbicides: current status and future trends. Weed Res., v.40, n.1, p.99-111, 2000.

EDNEY, N.A.; RIZVI, M. Phytotoxicity of fatty acids present in dairy and hog manure. J. Environ. Sci. Health., v.31, n.2, p.269-281, 1996.

EINHELLIG, F.A.; RASMUSSEN, J.A. Effects of tree phenolics acids on chlorophyll content and growth of soybean and grain sorghum. J. Chem. Ecol., v.5, n.2, p.815824, 1979.

EINHELLIG, F.A.; RICE, E.L.; RISSER, P.G.; WENDER, S.H. Effects of scolpoletin on growth, $\mathrm{CO}_{2}$ exchange rates, and concentration of scopoletin, scopolin and chlorogenic acids in tobacco, sunflower and pigweed. Bull. Torrey Bot. Club., v.97, n.1, p.22-23, 1970.

EINHELLIG, F. A. Mechanisms and modes of action of allelochemicals. In: PUTNAM, A.R.; TANG, C.H.S. (Eds). The Science of Allelopathy. Nova York: Nova John Wiley and Sons, 1986. p. 171-188.

FERREIRA, A.G.; BORGHETTI, F. Germinação: do básico ao aplicado. Porto Alegre: Artmed, 2006. 323 p.

GOODMAN, B.A.; MCPHAIL, D.B.; LINEHAN, D.J. Oxygeninduced free radical in wheat roots. Free Radic. Res. Commun., v.2, n.3, p.173-178, 1986.

GRAY, T.M.; ARNOYS, E.J.; BLANKESPOOR, S.; BORN, T.; JAGAR, R.; EVERMAN, R.; PLOWMAN, D.; STAIR, A.; ZHANG, D. Destabilizing effect of proline substitutions in two helical regions of T4 lysozyme: Leucine 66 to proline and leucine 91 to proline. Protein Sci. v. 5, n.4, p.742-751, 1996.

GUPTA, A.S.; WEBB, R.P.; HOLADAY, A.S.; ALLEN, R.D. Overexpression of Superoxide Dismutase Protects Plants from Oxidative Stress (Induction of Ascorbate Peroxidase in Superoxide Dismutase-Overexpressing Plants). Plant Physiol., v.103, n.4, p.1067-1073, 1993. 
HOSHINA, M.; MARIN-MORALES, M.A. Micronucleus and chromosome aberrations induced in onion (Allium cepa) by a petroleum refinery effluent and by river water that receives this effluent. Ecotoxicol. Environ. Saf., v.72, n.8, p.2090-2095, 2009.

INDERJIT, S.D.; DUKE, S.O. Ecophysiological aspects of allelopathy. Planta, v.217, n.4, p.529-539, 2003.

JENSEN, W.A. Botanical histochemistry: principles and practice. W. H. San Francisco: Freeman \& Co, 1962. 408 p.

KATO-NOGUCHI, H.; TANAKA, Y. Allelopathic potencial os Citrus junos fruit wast from food precessing industry. Bioresour. technol., v.94, n.2, p.211-214, 2004.

KHAN, S.R.A. Citrus quality to meet global demand. Pakistan agriculture overview. 2005. Available at: < http://goo. gl/4Sd1Jo>. Acessed on: Jul. 2009.

KERN, K.A.; PERGO, E.M.; KAGAMI, F.L.; ARRAES, L.S.; SERT, M.A.; ISHII-IWAMOTO, E.L. The phytotoxic effect of exogenous ethanol on Euphorbia heterophylla L. Plant Physiol. Biochem., v.47, n.11-12, p.1095-1101, 2009.

KRUSE, N.D.; VIDAL, R.A.; DALMARZ, C.; TREZZI, M.M.; SIQUEIRA, I. Estresse oxidativo em girasol (Helianthus annuus) indica sinergismo para a mistura dos herbicidas metribuzin e clomazone. Planta Daninha, v.24, n.2, p.379390, 2006.

LABOURIAU, L.G. The germination of seeds. Washington: OEA, 1983. 174 p.

LARCHER, W. Ecofisiologia vegetal. São Carlos: Rima, 2000. $531 \mathrm{p}$.

LIU, D.L.; AN, M.; JOHNSON, I.R.; LOVETT, J.V. Mathematical modelling of allelopathy: III. A model for curve-fitting allelochemical dose-responses. Nonlinearity in Biology. Toxic. Med., v.1, n.1, p.37-50. 2003.

MACIAS, F.A.; CASTELLANO, D.; MOLINILLO, J.M.G. Search for a standart phytotoxic biossay for allelochemicals. Selection of standard target species. J. Agric. Food Chem., v.48, n.6, p.2512-2521, 2000.

MAGUIRE, J.D. Speed of germination aid in selection and evaluation for seedling emergence and vigor. Crop. Sci., v.1, n.2, p.176-177, 1962.
MAHMOOD, M.A. Hurdles in way of Citrus export. Dawn News, 2005. Available at: <http://archives.dawn. com/2005/10/31/ebr4.htm>. Acessed on: Jul. 2009.

MANNER, H.I., BUKER, R.S., SMITH, V.E., WARD, D.; ELEVITCH, C.R. Species Profiles for Pacific Island Agroforestry: Permanent Agriculture Resources (PAR). Available at: <http://www.traditionaltree.org > . Acessed on: Jul. 2009.

MARAMBE, B.; NAGAOKA T.; ANDO, T. Identification and biological activity of germination-inhibiting long-chain fatty acids in animal-waste composts. Plant Cell Physiol., v.34, n.4, p.605-612, 1993.

MARQUES, M.R.; XAVIER-FILHO, J. Enzymatic and inhibitory activities of cashew tree gum exudate. Phytochemistry, v.30, n.5, p.1431-1433, 1991.

MAULI, M.M.; FORTES, A.M.T.; ROSA, D.M.; PICCOLO, G.; MARQUES, D.S.; CORSATO, J.M.; LESZCZYNSKI, R. Alelopatia de Leucena sobre soja e plantas invasoras. Semina: Ciências Agrárias, v.30, n.1, p.55-62, 2009.

MÜSEL, G.; SCHINDLER, T.; BERGFELD, R.; RUEL, K.; JAQUET, G.; LAPIEREE, C.; SPETH, V.; SCHOPEPFER, p.Structure and distribution of lignin in primary and secondary cell walls of maize coleoptiles analyzed by chemical and immunological probes. Planta, v.201, p.146159, 1997.

NASCIMENTO, J.E.; MELO, A.F.M.; LIMA E SILVA, T.C.; VERAS FILHO, J.; SANTOS, E.M.; ALBUQUERQUE, U.P.; AMORIM, E.L.C. Estudo fitoquímico e bioensaio toxicológico frente a larva de Artemia salina Leach. de três espécies medicinais do gênero Phyllanthus (Phyllanthaceae). Rev. Ciênc. Farm. Básica Apl., v.29, n.2, p.145-150, 2008.

NOCTOR, G.; FOYER, C.H. Ascorbate and glutathione: keeping active oxygen under control. Annu. Rev. Plant Biol., v.49, p.249-279, 1998.

OLIVEIRA, V.R.; SCAPIM, C.A.; OLIVEIRAJR, R.S.; PIRES, N.M. Efeito do herbicida trifluralin sobre a germinação de sementes e índice mitótico em raízes de milho (Zea mays L.). Rev. Unimar, v.18, n.1, p.537-544, 1996. 
PASSARDI F.; COSIO C.; PENEL C.; DUNAND C. Peroxidases have more function than a Swiss army knife. Plant Cell Rep., v.24, n.5, p.255-265, 2005.

PERES A.; CHURCHMAN M.L.; HARIHARAN S.; HIMANEN K.; VERKEST A.; VANDEPOELE K.; MAGYAR Z.; HATZFELD Y.; VAN DER SCHUEREN, E.; BEEMSTER G.T.S.; FRANKARD V.; LARKIN J.C.; INZÉ D.; VEYLDER L.D. Novel plant-specific cyclindependent kinase inhibitors induced by biotic and abiotic stresses. $J$. Biol. Chem., v.282, n.35, p.25588-25596, 2007.

PERGO, E.M.; ISHII-IWAMOTO, E.L. Changes in energy metabolism and antioxidant defense systems during seed germination of the weed species Ipomoea triloba L. and the responses to allelochemicals. J. Chem. Ecol., v.37, n.5, p.500-513, 2011.

PORTA, H.; ROCHA-SOSA, M. Plant Lipoxygenases. Physiological and Molecular Features. Plant Physiol., v.130, n.1, p.15-21, 2002.

PUNTARULLO, S.; GALLEANO, M.; SANCHEZ, R.A.; BOVERIS, A. Hydrogen peroxide metabolism in soybean embryonic axes at the onset of germination. Plant Physiol., v.86, n.2, p.626-630, 1988.

QUINTANA, N.; ELIE, G.; KASSIS, E.L.; STERMITZ, F.R.; VIVANCO, J.M. Phytotoxic compounds from roots of Centaurea diffusa Lam. Plant Signal Behav. v. 4, n.1, p.914, 2009.

QUiRoGA, M.; GUERRERO, C.; BOTELLA, M.A.; BARCELÓ, A.; AMAYA, I.; MEDINA, M.I.; ALONSO, F.J.; MILRAD, D.; FORCHETTI, S.; TIGIER, H.; VALPUESTA, v.A tomato peroxidase involved in the synthesis of lignin and suberin. Plant Physiol., v.122, n.4, p.1119-1128, 2000.

REIGOSA, M.J.; PEDROL N.; GONZÁLEZ L.; SÁNCHEZMOREIRAS A.M.; DE LA PEÑA, T.C.; REIGOSA, M.J. Cell cycle analyses for understanding growth inhibition. In: REIGOSA, M.J.; PEDROL, N. (Eds.). Allelopathy. New York: Springer, 2006. v.1. p.141-156.

RICE, E.L. Allelopathy. 2.ed. New York: Academic Press, 1984. $421 \mathrm{p}$.
RYAN, C.A. The systemin signaling pathway: differential activation of plant defensive genes. Biochim. Biophys. Acta, v.1477, n.2, p.112-121, 2000.

SCHIEBER, A.; STINTZING, F.C.; CARLE, R. Byproducts of plant food processing as a source of functional compounds: recent developments. Trends Food. Sci. Technol., v.12, n.11, p.401-413, 2001.

S C H M I D T-S I LVA, V.; PAW L O W S K I, Â.K.S .; ALCARAZ, E.Z.C.; SOARES, G. Cytotoxicity of essential oils from two species of Heterothalamus (Asteraceae). Aus. J. Bot., v. 59, n.01, p.682-691, 2011.

SIEDOW, J.N.; MOORE, A.L. The regulation and nature of the cyanide-resistant alternative oxidase of plant mitocochondria. Biochim. Biophys. Acta, v.1059, n.2, p.121-140, 1991.

SILVA, C.B.; SIMIONATTO, E.; GEBARA, S.S.; RÉ- POPPI, N.; RECH, K.S. PERES, M.T.L.P.; DIAS, J.F.G.; ZANIN, S. M.W.; MIGUEL O.G.; MIGUEL. M.D. Brachiaria decumbens and Ipomoea cordifolia exhibits High Sensitivity to Cyclic polysulfides from leaves of Microlobius foetidus. Allelopathy J., v.33, n.01, p.213-226, 2014.

SONG, H.K.; AHN, J.K.; AHMAD, A.; HAHN, S.J.; KIM, S.H.; CHUNG, I.M. Identification of allelochemicals in rice root exudates at various phenological phases and their influence on barnyardgrass. Allelopathy J., v.13, p.173-188, 2004.

STEPONKUS, P.L.; LANPHEAR, F.O. Refinement of the triphenyl tetrazolium chloride method of determining cold injury. J. Plant Physiol., v.42, n.1, p.1423-1426, 1967.

TAIZ, L.; ZEIGER, E. Fisiologia vegetal. Porto Alegre: Artmed, 2004. 719 p.

TEERARAK, M.; LAOSINWATTANA, C.; CHAROENYING, p.Evaluation of allelopathic, decomposition and cytogenetic activities of Jasminum officinale L.f. var. grandiflorum (L.) Kob. on bioassay plants. Bioresour. Technol., v.101, n.14, p.5677-5684, 2010.

THALER, J.S. Induced resistance in agricultural crops: effects of jasmonic acid on herbivory and yield in tomato plants. Environ. Entomol., v.28, n.1, p.30-37, 1999. 
WOJTYLA L.; GARNCZARSKA M.; ZALEWSKI T.; BEDNARSKI W.; RATAJCZAK L.; JURGA S. A comparative study of water distribution, free radical production and activation of antioxidative metabolism in germinating pea seeds. J. Plant Physiol., v.163, n.12, p.1207-1220, 2006.
XUAN, T.D.; TSUZUKI, E. Allelopathic plants: buckwheat (Fagopyrum spp.). Allelopathy J., v.13, n.2, p.137-148, 2004.

Received for publication on $09^{\text {th }}$ October 2013 Accepted for publication on $15^{\text {th }}$ January 2015 
